\title{
Effects of Monetary Policy on Economic Growth; Evidence from Five (5) African Countries (Mauritius, Nigeria, South Africa, Namibia and Kenya) from 1980 to 2019
}

Asiedu Michael $^{1 *}$, Emmanuel Owusu Oppong ${ }^{2}$, Orazgylyjova Gulnabat ${ }^{2}$

${ }^{1}$ School of Finance, Zhongnan University of Economics and Law, Wuhan, China

${ }^{2}$ School of Finance, Central Uinversity of Finance and Economics, Beijing, China

DOI: $10.36347 /$ sjebm.2020.v07i09.002

| Received: 21.08.2020 | Accepted: 29.08.2020 | Published: 02.09.2020

*Corresponding author: Asiedu Michael

Abstract

Original Research Article

While it is not rare to find sufficient literature and evidence on the roles and impact of monetary policy in industrialized economies in achieving macroeconomic objectives such as economic growth, employment and price stability among others; the evidence however from developing economies remain predominantly inconclusive and insufficient largely due to data challenges and structural rigidities within their financial setup and unlimited political interference in the implementation of monetary policy. This suggests that the success of monetary policy in any economy does not only depend to the choice of policy tool but also on other fundamentals such as the financial openness of the entire economy. In this study, we evaluated the efficacy of monetary policy in five (5) African countries from 1980 to 2019 since most of the existing studies are limited to analysis on individual countries. Using panel regression analysis and fixed effect model with data set from World Bank database after ensuring that all the variables are stationary (unit root test). We established the presence of a monetary transmission mechanism flowing from higher growth in broad money to higher rates of inflation through to higher rates of economic growth. Positive growth in broad money caused significant increase in economic growth but with inflationary pressure in these countries. We therefore call for sound and positive growth in broad money in these five (5) African countries to achieve a positive balance between economic growth and price stability. Given the relatively stable political and socioeconomic conditions prevailing in these countries, it is necessary for monetary policymakers to institute sound and prudent measure to create the right environment for monetary policy to succeed.

Keywords: Monetary Policy, Economic Growth, Broad Money Growth, Inflation, Risk Premium, Interest Rate Spread.

Copyright @ 2020: This is an open-access article distributed under the terms of the Creative Commons Attribution license which permits unrestricted use, distribution, and reproduction in any medium for non-commercial use (NonCommercial, or CC-BY-NC) provided the original author and source are credited.

\section{INTRODUCTION}

Monetary policy is one among two key policies (monetary policy and fiscal policy) available to policy makers and economic managers to regulate economic activities in an economy towards achieving a set of macroeconomic goals. Monetary policy involves a set of tools particularly designed to change or influence money supply to achieve targeted objectives including economic growth, price stability, employment and desirable balance of payment account among others. According to Fisher the success of conducting monetary policy demands the total understanding of the monetary transmission mechanisms due to the need to maintain sufficient liquidity to facilitate transactions while ensuring price stability or without inflationary pressure in the economy [1]. To achieve sustainable economic growth, stable macroeconomic conditions are needed to guarantee such. In the words of Mankiw a thorough understanding of what monetary policy can achieve in terms of economic performance will be a major catalyst for policy makers; however it is still a significant challenge to policy makers in all economies [2]. It is important therefore to measure how monetary policy affects the macro-economy and also how it is affected by other macro-economic variables for prudent economic decision making.

This study therefore seeks to ascertain the effect of monetary policy on economic growth reference to five (5) African economies (Mauritius, Nigeria, South Africa, Namibia and Kenya) from 1980 to 2019 considering the critical roles of monetary policy in achieving sustainable economic growth. 


\section{LITERATURE REVIEW}

In the face of the avalanche of literature on the effects and efficacy of monetary policy; two schools of thoughts namely Keynesians and the Monetarists come to mind. Khabo opined that, whilst Keynesians are of the view that money has no direct and central role in the economy, and changes in the money supply are unable to affect economic growth significantly, they suggested that the key connection between monetary aggregates and the output side of the economy is weak [3]. Keynesians are also of the view that changes in the monetary base only affects production indirectly through interest rate and investment. This transmission mechanism from changes in the monetary base to aggregate investment is in the form of three steps: an expansionary monetary policy (increase in money supply) will lead a fall in interest rates and thereby boosting investment which will result in an increase in national income. Conversely, a contractionary monetary policy will have the exact opposite transmission mechanism effect to a fall in national income. The Monetarist however, are of the firm believe that money does matter at least in the short term; hence calling for the adoption of monetary policy in shaping economic growth since they believe a direct link exist between the real economy and monetary variables. Friedman stated that national income responds to any form of change in monetary aggregates [4]. Assuming the government through the central bank undertakes an expansionary policy by increasing the supply of money through the purchase of securities on the open market, this will cause an increase in the price and a fall in interest rates. The effect of this will be the sale of securities by holders for more money balances and spending such extra liquidity on consumer goods and on other financial assets. The lower interest rate also serves as an inducement for consumers to borrow from financial institutions and banks. This phenomenon will culminate into an increase in spending and revenue in the entire economy through the Tobin's effect.

In the view of the Monetarist, recessions and depressions occur anytime there is a prolonged and sharp fall in money supply whilst periods of booms and expansions in the economy are associated with increases in the supply of money.

Zettelmeyer, $\mathbf{J}$ from his analysis on how exchange rate is impacted by monetary policy shocks in the 1990s in Australia, Canada and New Zealand found that exchange rate appreciated by 2-3 percent following a 100 basis point negative shock in money supply [5]. Miftahu Idris using annual data from1980 to 2017 found the presence of a positive long-run relationship through co-integration and OLS estimation technique after examining the relationship between monetary policy and economic growth in Nigeria Meanwhile exchange rate and interest rate were found to be negatively related to economic growth [6]. Chipote and Makhetha using Johansen co-integration and the Error
Correction Mechanism from 2000 to 2010 found that money supply, repo rate and exchange rate are all not significant monetary policy instruments that enhance economic growth in South Africa but inflation positively and significantly drives economic growth [7]. In another study conducted by Berument and Dincer, using a VAR type of model identified monetary policy for the period 1986 to 2000 for a less developed economy like Turkey. Their measure for monetary policy was the difference between the rate of depreciation their currency and the interbank interest rate of the Central Bank. They found that tight and contractionary monetary policy has a temporal effect on output but permanent and significant consequences of price [8].

Akalpler and Duhok, in their study of the efficacy of monetary policy in Malaysia found a positive link between inflation and the growth of the Malaysian economy [9]. In terms of magnitude, they found that every unit change in inflation will lead to a corresponding $77 \%$ rise in the growth of the economy. Their study also recorded a positive linkage between interest rate and economic growth while the growth in money supply in Malaysia contributed 0.02 on the average to the growth of the economy. Vargas-Silva, C also recorded a negative effect between housing starts, residential investment and negative shocks in monetary policy in US using an identification method that employs signed restrictions on the elasticities of given variables for set of period [10].. In addition the results obtained through the traditional Choleski decomposition, revealed that monetary policy has less impact using the signed restrictions method. Kovanen in his analysis of interest rate pass-through in Ghana found that the efficacy of the changes to Central Bank's policy rate are gradual and slow in wholesale markets; hence persistent deviations of the interbank rates from the central bank policy rate signify the constrains faced by the monetary authorities of Ghana when targeting money market rates [11]. The constraints in the wholesale market adjustment are mostly due to weak liquidity management and policy credibility. Moreover, with the retail market; pass through from deposit to lending rates are highly constrained and incomplete. Ahearne et al., focusing on eighteen industrialized countries with special attention on the ramifications of monetary policy on real house prices right from 1970 [12]. They found that real house prices co-moves with real output, inflation, household consumption, budget, investment, gaps in outputs and is pro-cyclical. Lastrapes, W. D also established that an expansionary money supply shock has positive and significant real effect on housing prices and sales through a vector auto-regression estimation method [13]. Rigobon and Sacks in their analysis of how assets prices are impacted by changes in monetary policy developed a unique estimator based on the presence of heteroskedasticity in high trading frequency data. They came to the conclusion that stock prices fall following a 
rise in short term rates and the yield curve also shifts upward and gets smaller for longer maturities. In addition, they derived that; estimates from event-study have biases that influence the estimated impacts on stock prices to look negligible and the effect to be so significant on Treasury yields.

Folawewo and Osinubi adopted quarterly data from the first quarter of 1980 to the fourth quarter of 2000 found that attempts to influence the finance of federal government deficits in Nigeria through the setting inflation-tax rate impacts both exchange rate and inflation rate which results in exchange rate volatility. They also found that inflation does not only affect its own volatility but also the real exchange rate [15]. Using data from 1974 to 2008 and least squares methods Nouri M. and Samimi J also accessed how changes in monetary aggregates in Iran affects the growth of their economy [17]. They established that growth in money supply positively affected the growth rate of the Iranian economy. Benziane using a VAR model on quarterly data from 1990 to the year 2017 found that the rate of interest and credit effect was insignificant on the growth of national output in Algeria [16]. Uhlig, $\mathrm{H}$ with a unique agnostic estimation technique could not find a clear cut effect of a negative shock in monetary policy on real output, despite the fact that prices change slowly in reaction to shocks in monetary policy. Also found to be consistent is that; monetary policy shock was neutral with the data [18]. In a sharp contrast Weise, C. L however; found that shocks to money supply recorded major effect on output and weaker effects on prices at lower levels of output after testing for nonlinearity using a standard VAR estimation method consisting of output, supply of money and price levels. In addition, near proportional effect was recorded as response for both positive and negative shocks in monetary policy [19]. It is therefore clear from the existing literature sampled so far that the results on how changes in monetary aggregates affects the growth rates of both developed and less developed economies, has been inconclusive even though some studies have found significant relationships but the direction still remains inconclusive.

\section{Data Size and Source}

The study employs secondary data over a 40 year period from 1980 to 2019 sourced from the World Bank database for the five countries; namely Mauritius, Nigeria, South Africa, Namibia and Kenya.

\section{METHODOLOGY}

To achieve the objective of the study, of how changes in monetary aggregates influence economic growth; the following standard model is adopted; $\mathrm{GDPg}=f\left(\mathrm{BMG}, \mathrm{Infl}, \mathrm{GFCFg}, \mathrm{IRS}, \mathrm{RP}, \mathrm{BMRR} \mathrm{GDPg}_{-1}, \mu\right)$

Where,

GDPg is annual GDP growth rate and is the main dependent variable. The independent variables include annual inflation rate (Infl), annual Broad Money Growth (BMG), annual growth rate of gross fixed capital formation (GFCFg), annual Interest Rate Spread (IRS), annual Risk Premium (RP) annual growth of broad money to GDP (BMRR) and all other relevant variables that are potentially not captured in the model are represented by the stochastic error term as $\mu$.

This is finally transformed as:

$$
\mathrm{GDPg}=\beta_{0}+\beta_{1} \mathrm{BMG}+\beta_{2} \mathrm{Infl}+\beta_{3} \mathrm{GFCFg}+\beta_{4} \mathrm{IRS}+\beta_{6} \mathrm{RP}+\beta_{7} \mathrm{BMRR}+\beta_{8} \mathrm{GDPg}_{-1}+\varepsilon_{\mathrm{t}} \ldots \ldots \ldots \ldots \text { (1) }
$$

To avoid dummy variable trap; the number of c ountry dummies are reduced to four (W-1); where $\mathrm{W}$ is the number of countries. Let Dummy Ma = country Ma uritius. Dummy_Na $=$ country Namibia, Dummy_Ni $=$ country Nigeria, Dummy_Sa = country South Africa as reported in the main regression table; with Kenya is the base country.

\section{The Pooled OLS Regression}

The pooled OLS regression is computed with the assumption of the homogeneity of the variances of the random error among countries; such that $\phi_{i}^{2}=\phi_{t}^{2}$;

$$
\text { Yit }=\chi_{1} \beta_{1 \text { it }}+\chi_{2} \beta_{2 \text { it }}+\chi_{3} \beta_{3 i t}+\ldots \ldots .+K_{i t} \phi+\varepsilon_{i t}
$$

Equation (2) is further transformed with the introduction of dummy variables for the individual homogeneity of variances of the random error term among the countries; such that $\operatorname{cov}\left(e_{i t}, e_{j s}\right)=0$ for $\mathrm{i} \neq \mathrm{j}$; zero covariance among the countries

\section{The Fixed Regression Model}

The fixed effect model is presented in the form of a linear regression model in which the intercept term vary based on the individual observations under the assumption that all the independent variables $K_{i t}$ are not correlated with the error term $\varepsilon_{i t}$. This is expressed as:

$$
\text { Yit }=\sum_{j=1}^{s} \cdot \chi_{\mathrm{j}} \mathrm{y}_{\mathrm{ij}}+\mathrm{K}_{\mathrm{it}} \phi+\varepsilon_{\mathrm{it}}
$$

countries: given that there are $\mathrm{S}$ set of dummy variables in the model and $y_{i j}=1$ if $\mathrm{i}=\mathrm{j}$ and zero $(0)$ elsewhere. 
Table-1: Descriptive Statistics

\begin{tabular}{|l|l|l|l|l|l|}
\hline Variable & Obs & \multicolumn{1}{|c|}{ Mean } & Std.Dev. & Min & Max \\
\hline GDPg & 200 & 3.366 & 3.438 & -13.128 & 15.329 \\
\hline Infl & 200 & 11.026 & 10.322 & -.692 & 72.836 \\
\hline BMG & 200 & 17.206 & 12.198 & -.794 & 87.761 \\
\hline GFCFg & 199 & 3.066 & 12.322 & -30.172 & 40.389 \\
\hline IRS & 200 & 6.364 & 3.631 & .317 & 20.52 \\
\hline RP & 200 & 5.592 & 3.801 & -25.715 & 16.512 \\
\hline BMRR & 199 & 6.881 & 6.147 & .648 & 37.685 \\
\hline \multicolumn{7}{|l}{} \\
\hline
\end{tabular}

Table- 1 above is the descriptive statistic of the variables in this study. Columns (3) and (4) reports the mean and standard deviations of the variables respectively. The values of the standard deviation as reported in column (4) exhibits very high variations from their mean except GDPg. The mean value for annual GDP growth rate (GDPg), annual inflation rate
(Infl), annual Broad Money Growth (BMG), annual growth rate of gross fixed capital formation (GFCFg), annual Interest Rate Spread (IRS), annual Risk Premium (RP) annual growth of broad money to GDP (BMRR) averaged at 3.37\%, 11\%, 17.2\%, 3.1\%, 6.3\%, $5.6 \%, 6.9 \%$ respectively.

Table-2: Pairwise correlation matrix

\begin{tabular}{|c|c|c|c|c|c|c|c|}
\hline Variables & (1) & (2) & (3) & (4) & (5) & (6) & $(7)$ \\
\hline (1) GDPg & 1.000 & & & & & & \\
\hline (2) Infl & $-0.26^{*}$ & 1.000 & & & & & \\
\hline (3) BMG & 0.105 & $0.31 *$ & 1.000 & & & & \\
\hline (4) GFCFg & $0.39 *$ & $-0.15 *$ & 0.028 & 1.000 & & & \\
\hline (5) IRS & 0.091 & 0.081 & $0.21 *$ & 0.109 & 1.000 & & \\
\hline (6) RP & $0.17 *$ & -0.09 & 0.114 & 0.045 & $0.68 *$ & 1.000 & \\
\hline (7) BMRR & $-0.26^{*}$ & 0.043 & 0.077 & -0.07 & -0.06 & -0.04 & 1.000 \\
\hline
\end{tabular}

Table-2 above also reports the results of the correlation matrix among the variables with their level of significance. The matrix results points that the variables are weakly correlated and are mostly statistically significant at $5 \%$. The weak correlation result is a good indication of the model overcoming the problem of multicollinearity.

\section{Hausman Test}

The results from Hausman test as it is done in literature to decide the choice of model between the fixed and random effect model for the analysis gave a Ch-Sq value of 114.721 and this is highly significant with the probability 0.000 ; the fixed effect model is therefore adopted in this analysis.

Hausman (1978) specification test

\section{Hausman (1978) specification test}

\begin{tabular}{|l|l|}
\hline & Coef. \\
\hline Chi-square test value & 114.721 \\
\hline P-value & 0.000 \\
\hline
\end{tabular}

\begin{tabular}{|l|l|l|l|l|}
\hline & $(\mathbf{b}) \mathbf{f e}$ & $(\mathbf{B}) \mathbf{R e}$ & $(\mathbf{b}-\mathbf{B})$ Difference & Sqrt(diag(V_b V_B)) S.E \\
\hline GDPg & -.9675495 & -.9787995 & .0112501 &. \\
\hline BMG & .1974877 & .2869036 & -.0894159 & .0084064 \\
\hline GFCFg & .0163126 & -.0444189 & .0607315 & \\
\hline IRS & .481272 & .4824216 & -.0011496 & .0891844 \\
\hline RP & -.5225651 & -.5294167 & .0068516 & .0399407 \\
\hline BMRR & .2080662 & -.0902326 & .2982988 & .050086 \\
\hline GDPg $_{-1}$ & .1722047 & .1703269 & .0018778 &. \\
\hline
\end{tabular}




\section{Main Regression Table}

Table-3: Regression results

\begin{tabular}{|c|c|c|c|c|c|c|}
\hline & (1) Pooled & (2) Fixed Effect & (3) Pooled & (4) Fixed Effect & (5) Pooled & (6) Fixed Effect \\
\hline & Infl & Infl & BMG & BMG & GDPg & GDPg \\
\hline \multirow[t]{2}{*}{ GDPg } & -0.968 *** & $-0.968 * * *$ & $0.882 * * *$ & $0.882 * * *$ & & \\
\hline & $(0.217)$ & $(0.217)$ & $(0.278)$ & $(0.278)$ & & \\
\hline \multirow[t]{2}{*}{ BMG } & $0.197 * * *$ & $0.197 * * *$ & & & $0.058 * * *$ & $0.058 * * *$ \\
\hline & $(0.057)$ & $(0.057)$ & & & $(0.018)$ & $(0.018)$ \\
\hline \multirow[t]{2}{*}{ GFCFg } & 0.016 & 0.016 & 0.028 & 0.028 & $0.077 * * *$ & $0.077 * * *$ \\
\hline & $(0.056)$ & $(0.056)$ & $(0.070)$ & $(0.070)$ & $(0.017)$ & $(0.017)$ \\
\hline \multirow[t]{2}{*}{ IRS } & $0.481 *$ & $0.481 *$ & $0.661 * *$ & $0.661 *$ & -0.089 & -0.089 \\
\hline & $(0.270)$ & $(0.270)$ & $(0.337)$ & $(0.337)$ & $(0.087)$ & $(0.087)$ \\
\hline \multirow[t]{2}{*}{$\mathrm{RP}$} & $-0.523 * *$ & $-0.523 * *$ & -0.117 & -0.117 & 0.111 & 0.111 \\
\hline & $(0.245)$ & $(0.245)$ & $(0.309)$ & $(0.309)$ & $(0.079)$ & $(0.079)$ \\
\hline \multirow[t]{2}{*}{ BMRR } & $0.208 *$ & $0.208 *$ & $0.397 * * *$ & $0.397 * * *$ & -0.039 & -0.039 \\
\hline & $(0.122)$ & $(0.122)$ & $(0.151)$ & $(0.151)$ & $(0.039)$ & $(0.039)$ \\
\hline \multirow[t]{2}{*}{$\mathrm{GDPg}_{-1}$} & 0.172 & 0.172 & -0.331 & -0.331 & $0.307 * * *$ & $0.307 * * *$ \\
\hline & $(0.213)$ & $(0.213)$ & $(0.265)$ & $(0.265)$ & $(0.065)$ & $(0.065)$ \\
\hline \multirow[t]{2}{*}{ Dummy_Ma } & -2.283 & & 2.865 & & -0.672 & \\
\hline & $(2.152)$ & & $(2.689)$ & & $(0.691)$ & \\
\hline \multirow[t]{2}{*}{ Dummy_Na } & $-4.989 * *$ & & $6.121 * *$ & & $-1.225^{*}$ & \\
\hline & $(2.001)$ & & $(2.502)$ & & $(0.647)$ & \\
\hline \multirow[t]{2}{*}{ Dummy_Ni } & $6.647 * * *$ & & $10.369 * * *$ & & -0.217 & \\
\hline & $(2.229)$ & & $(2.748)$ & & $(0.732)$ & \\
\hline \multirow[t]{2}{*}{ Dummy_Sa } & $-4.114 *$ & & 0.608 & & -1.190 & \\
\hline & $(2.266)$ & & $(2.856)$ & & $(0.729)$ & \\
\hline \multirow[t]{2}{*}{ Infl } & & & $0.308 * * *$ & $0.308 * * *$ & $-0.100 * * *$ & $-0.100 * * *$ \\
\hline & & & $(0.089)$ & $(0.089)$ & $(0.022)$ & $(0.022)$ \\
\hline \multirow[t]{2}{*}{ _cons } & $9.662 * * *$ & $8.671 * * *$ & 1.714 & $5.694 * *$ & $3.058 * * *$ & $2.392 * * *$ \\
\hline & $(2.408)$ & $(1.837)$ & $(3.133)$ & $(2.393)$ & $(0.774)$ & $(0.599)$ \\
\hline Obs. & 198 & 198 & 198 & 198 & 198 & 198 \\
\hline R-squared &. $\mathrm{Z}$ & 0.213 &. $\mathrm{z}$ & 0.171 &.$z$ & 0.364 \\
\hline
\end{tabular}

\section{DISCUSSION OF RESULTS}

Table- 3 above is the summary presentation of the pooled OLS and fixed effect models analyzing how changes in monetary aggregates affects the growth rates of the economies of the countries under consideration through a transmission mechanism. Analyzing the fixed effect models in columns (2), (4) and (6) with inflation, the growth of broad money and the growth rate of GDP as the dependent variables respectively. For column (2), GDP growth and broad money growth (BMG) are statistically significant at $1 \%$, interest rate spread (IRS) and broad money growth as percentage of GDP are also statistically significant at $10 \%$ and risk premium is also statistically significant at $5 \%$. The result also finds that a negative sign exist between inflation and GDP growth and a positive sign exist between inflation and broad money growth.

In column (4), the monetary transmission mechanism is again approved by finding a positive and statistically significant relationship flows from the growth rate in broad money to inflation. This finding is consistent with the general view held by the monetarist that inflation is indeed everywhere a monetary phenomenon and also supported by the findings of Akalpler and Duhok in Malaysia [9]. Finally in column (6), with GDP growth as the measure of economic growth serving as the dependent variable; we find that broad money growth (BMG), Inflation (Infl), gross fixed capital formation growth (GFCFg) and the one year lag of GDP growth are all positively (except inflation with is negative) and statistically significant at $1 \%$. This result is very consistent with the monetarist assertion that indeed money matters. For instance, for every percentage increase in broad money growth will lead to 0.058 increase in economic growth in the countries. We find these results are a significant breakthrough in advising and shaping the use of monetary policy tools to achieve core macroeconomic goals of economic growth, price stability and employment. These findings are also consistent and corroborated in the literature by the findings of Lastrapes, W. D; Nouri M. Samimi J in Iran $[13,16]$. 


\section{CONCLUSION}

Base on the results from the Hausman test, fixed effect model was used to investigate how economic growth is affected by changes in monetary policy in five (5) African countries (Mauritius, Nigeria, South Africa, Namibia and Kenya) from 1980 to 2019.

From a monetary transmission mechanism approach, the study found that broad money growth positively and significantly influenced inflation; but inflation negatively and significantly affected economic growth in these five countries.

We also found that broad money growth positively affected economic growth at $1 \%$ significant level in these countries, however; the study also recorded a significant positive effect between inflation and broad money growth. It must also be stated that the study did not find significant relationship between economic growth and interest rate spread (IRS), risk premium (RP) but found that, a significant sign exist between interest rate spread (IRS) and inflation. These findings mean that prudent monetary policies in these countries will lead to the achievement of the macroeconomic objective of economic growth.

\section{REFERENCES}

1. Fisher S. Growth, Macroeconomics, and Development. NBER Macroeconomics Annual. 1991; 6: 329-379.

2. Mankiw G. Principles of Economics, South Western Publications. 2003.

3. Khabo VS. The Impact of Monetary Policy of the Economic Growth of a Small and Open Economy: The case of South Africa. Department of Economics, University of Pretoria. 2002.

4. Friedman M. Monetary Policy: Theory and Practice. Journal of Money, Credit and Banking. February 14, 1982; 98-118.

5. Zettelmeyer J. The impact of monetary policy on the exchange rate: Evidence from three small open economies. Journal of Monetary Economics. 2004; 51(3), 635-652.

6. Idris M. Monetary Policy and Economic Growth in Developing Countries: Evaluating the Policy Nexus in Nigeria. Journal of Business and Economics Research. 2019 Aug 26;8(5):303-13.

7. Precious C, Makhetha-Kosi P. Impact of monetary policy on economic growth: A case study of South Africa. Mediterranean journal of social sciences. 2014 Jul 3;5(15):76-.

8. Berument H, Dincer IN. Measuring the effects of monetary policy for Turkey. Bilkent University Journal of Economic Cooperation. 2008; 29(1):83-110.

9. Akalpler E, Duhok D. Does monetary policy affect economic growth: Evidence from Malaysia. Journal of Economic and Administrative Sciences. 2018 May 8.

10. Vargas-Silva C. Monetary policy and the US housing market: A VAR analysis imposing sign restrictions. Journal of Macroeconomics. 2008 Sep 1;30(3):977-90.

11. Arto K. Monetary Policy Transmission in Ghana" Does the Interest Rate Channel Work? IMF Working Paper WP/11/275. 2011.

12. Ahearne AG, Ammer J, Doyle BM, Kole L, Martin RF. Monetary policy and house prices: a cross-country study. FRB International Finance Discussion Paper. 2005 Sep(841).

13. Lastrapes WD. The real price of housing and money supply shocks: time series evidence and theoretical simulations. Journal of Housing Economics. 2002 Mar 1;11(1):40-74.

14. Rigobon R, Sack B. The impact of monetary policy on asset prices. Journal of Monetary Economics. 2004 Nov 1;51(8):1553-75.

15. Folawewo AO, Osinubi TS. Monetary policy and macroeconomic instability in Nigeria: A rational expectation approach. Journal of Social sciences. 2006 Mar 1;12(2):93-100.

16. Nouri M, Jafari-Samimi A. The Impact of Monetary Policy on Economic Growth in Iran. Middle-East Journal of Scientific Research. 2011; 9(6):740-743.

17. Benziane R. The Impact of Monetary Policy on Algerian Economic Activity. Journal of Business and Economic Development. 2019; 4(1):15-22.

18. Uhlig $\mathrm{H}$. What are the effects of monetary policy on output? Results from an agnostic identification procedure. Journal of Monetary Economics. 2005; 52(2):381-419.

19. Weise CL. The asymmetric effects of monetary policy: A nonlinear vector autoregression approach. Journal of Money, Credit and Banking. 1999; 31(1):85-108. 